ORR, A. H (2001): The genetics of species differences. Trends in Ecology and Evolution 16: 343-349.

PANova, M., J. Hollander and K. JohanNESSON (2006): Site-specific genetic divergence in parallel hybrid zones suggests nonallopatric evolution of reproductive barriers. Molecular Ecology doi: 10.1111/j.1365-294X.2006. 03067.x.

Pritchard, J. K. and N. A. Rosenberg (1999): Use of Unlinked Genetic Markers to Detect Population Stratification in Association Studies. American Journal of Human Genetics 65: 220-228.

PRITChARD, J. K. and M. PRZEWORSKI (2001): Linkage disequilibrium in humans: models and data. American Journal of Human Genetics 69: 1-14.

RAYMOND, M. and F. RousseT (1995): An exact test for population differentiation. Evolution 49: 1280-1283.

RICE, W. R. (1989): Analyzing tables of statistical tests. Evolution 43: 223-225.

ROBERTSON, A. (1975): Remarks on the LewontinKrakauer test. Genetics 80: 396-396.

Schneider, D., D. Roessli and L. Excoffier (2000): ARLEQUIN, pp. A software for population genetics data analysis. Genetics and Biometry Laboratory, University of Geneva, Geneva.
Shepherd, M., S. Kasem, D. Lee and R. Henry (2006): Construction of microsatellite genetic linkage maps for Corymbia. Silvae Genetica 55: 228-238.

SLATKIN, M. (1995): A measure of population subdivision based on microsatellite allele frequencies. Genetics 139: 457-462.

Southerton, S. G., P. BirT and H. A. Ford (2004): Review of gene movement by bats and birds and its potential significance for eucalypt plantation forestry. Australian Forestry. 67: 44-53.

Thamarus, K. A., K. Groom, J. Murrel, M. Byrne and G. F. Moran (2002): A genetic linkage map for Eucalyptus globulus with candidate loci for wood, fibre, and floral traits. Theoretical and Applied Genetics 104: 379-387.

WeIR, B. S. and C. C. Cockerham (1984): Estimating F-Statistics for the Analysis of Population Structure. Evolution 38: 1358-1370.

WRIGHT, S. (1969): Evolution and genetics of populations II. The theory of gene frequencies. University of Chicago press.

Wu, C. I. (2001): The genic view of the process of speciation. Journal of Evolutionary Biology 14: 851-865.

\title{
Pollen Dispersal and Its Spatial Distribution in a Seed Orchard of Larix kaempferi (Lamb.) Carr.
}

\author{
By Zhang Zhuowen*), Sui Juanjuan, Mei Li and Shu Changqing
}

Faculty of Horticulture and Forestry Science, Huazhong Agricultural University, Wuhan 430070, P. R. China

(Received $4^{\text {th }}$ May 2007)

\begin{abstract}
Pollen dispersal and its spatial distribution in a seed orchard of Larix kaempferi in Changlinggang, Jianshi, Hubei Province has been studied for 3 years. The results show that pollen dispersal is directly affected by weather conditions, with wind speed being the main factor controlling pollen dispersal. Pollen dispersal follows a date rhythm of low-high-low during the whole pollen dispersal season with a peak date for 3-5 days, and a time rhythm of low-high-low with the peak time at 10:00-16:00 during the day. For pollen density in the air there are significant differences among dates, and among different day times during dispersing. There are no significant differences between pollen densities in space with regard to horizontal directions, 8 orientations, and different positions in the tree crown in this seed orchard, in all of these cases pollens are evenly distributed. There are significant differences for pollen densities among different vertical heights, showing a cluster distribution type. The pollination level in this seed orchard is very low and needs a supplement mass pollination (SMP).
\end{abstract}

*) E-Mail: zzhwzhang@@mail.hzau.edu.cn
Key words: Larix kaempferi (Lamb.) Carr, seed orchard, pollen dispersal, spatial distribution, pollination level.

\section{Introduction}

Larix kaempferi is a deciduous tree belonging to the genus Larix, family Pinaceae. It grows very fast with the characteristic of being tolerant to water logged soils, and its timber is widely used for its high quality. Both male cones and female cones grow on the same mature tree. The seed yield per Larix kaempferi mother tree is very low. Based on the data of the grafted Larix kaempferi clonal seed orchard located at Dagujia, Liaoning Province, Wang YoucAi et al. (WANG YoucAi et al., 2000) found that the seed yield was $2110 \mathrm{~kg} \cdot \mathrm{a}^{-1} \cdot \mathrm{hm}^{-2}$, $25100 \mathrm{~kg} \cdot \mathrm{a}^{-1} \cdot \mathrm{hm}^{-2}$ and $16143 \mathrm{~kg} \cdot \mathrm{a}^{-1} \cdot \mathrm{hm}^{-2}$ for trees younger than 16 years, between 22 to 26 years old, and between 27 to 31 years old, respectively. A seed-bearing periodicity phenomenon of bumper year - off year is very common in a seed orchard. The seed production is not enough for local afforestation at the moment. This situation may be related to pollination in the seed orchard, Wu DeJun et al. (Wu DEJUn et al., 1997) found 
in their research carried out in a seed orchard located in Liaoning province that Larix kaempferi pollen had no sac and that the wind was the medium for pollination. Since until now nobody has studied pollen release, dispersal and pollen distribution in a seed orchard, it is necessary to carry out a research project to study these characteristics. Our research carried out during 2004-2006 shows that there are some problems for pollination in the seed orchard, and a supplement mass pollination (SMP) is very useful for improving genetic quality and producing more seeds. We studied the characteristics of Larix kaempferi pollination, such as the pollen dispersal rhythm, pollen spatial distribution, and the level of pollination. The seed-bearing periodicity phenomenon may be overcome by means of a supplement mass pollination (SMP) in the seed orchard.

\section{Materials and Methods}

\subsection{The basic information of the seed orchard studied}

A research program was carried out concerning pollen dispersal, spatial distribution, and pollination level in the seed orchard of Larix kaempferi located at Changlinggang, Jianshi County, Hubei Province. The seed orchard is located at latitude $30^{\circ} 48^{\prime}$, longitude $110^{\circ} 03^{\prime}$ and an elevation of $1690-1817 \mathrm{~m}$. It has a subalpine vegetation (Fig. 1). The average annual temperature is $9{ }^{\circ} \mathrm{C}$, with the highest temperature $27^{\circ} \mathrm{C}$ in July, and the lowest temperature $-10^{\circ} \mathrm{C}$ in January. The annual rainfall is $1800 \mathrm{~mm}$, the relative humidity is more than $80 \%$ and 160 days are frost-free per year. The climatic condition is suitable for Larix kaempferi growth (WU YIQIANG et al., 2000). Larix kaempferi trees was introduced into Changlinggang in 1959, and the first generation clonal seed orchard was built afterwards. Stock was the normal tree, seedlings planted at $4 \times 4 \mathrm{~m}$ spacing, which were grafted between 1991 and 1995 with more than 600 clone scions from northeastern provinces of China. The basic information of the seed orchard was shown in Table 1. The seed orchard is divided into A, B and C districts by the path (Fig. 1).

\subsection{The research methods}

Pollen collectors were used to obtain pollen samples in the air. The collector was built with a bottom board and a cover board $\left(15 \times 15 \mathrm{~cm}^{2}\right.$, and $10 \mathrm{~cm}$ apart), and two boards were nailed on two wooden sticks $(1 \times 1 \times 10 \mathrm{~cm})$

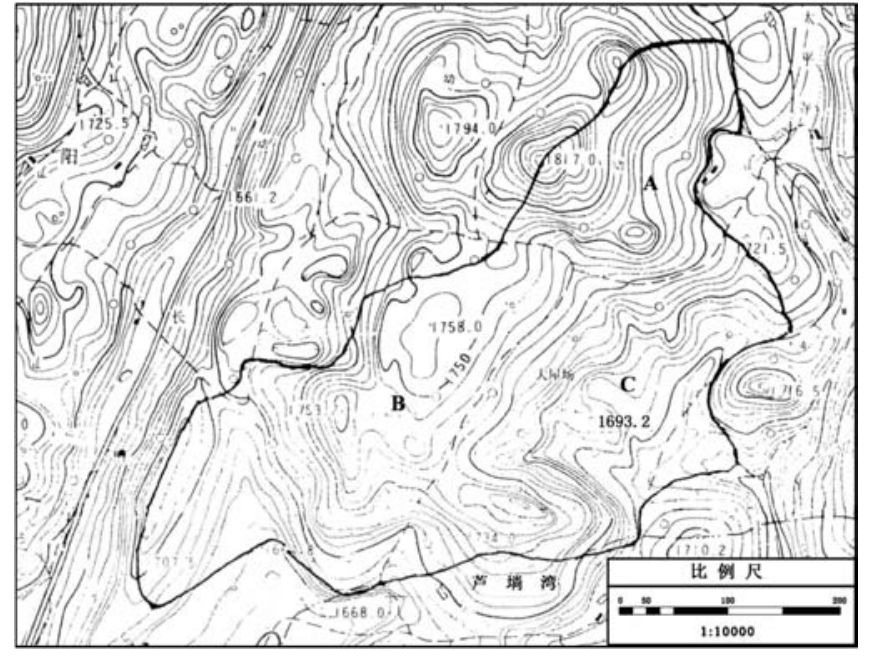

Figure 1. - A map of the seed orchard of Larix kaempferi located at Changlinggang.

for ventilation in all directions. Before a slide glass was put at the proper place of the pollen collector it was covered with some Vaseline in order to catch pollens in the air. Temperature, relative humidity, wind speed and atmospheric pressure were recorded at the same time when slide glasses were collected. Pollen numbers in 3-5 views under a microscope $(10 \times 10)$ per slide glass $($ ZHANG ZHUOWEN, 2002a) were counted. Collectors with one slide glass each were placed at different directions, different topographies and different heights in district A, B and $\mathrm{C}$ of the seed orchard. Slides were set up at $1.5 \mathrm{~m}$ height from the ground, and sample slide glasses were collected at 8 to 10 a.m. every day during pollen dispersal season. Collectors in district A were on an eastern slope, collectors in district B on a north-eastern slope and collectors in district $\mathrm{C}$ on a southeastern slope, 5-10 collectors were put in each district. 2 to 3 vertical plots in each district were set up as well, and each vertical plot had 5 pollen collectors (each collector with 1 slide glass) at ground, crown bottom, $1 / 2 \mathrm{H}, 2 / 3 \mathrm{H}$ and $\mathrm{H}$ height ( $\mathrm{H}$ here means the average height of trees in the seed orchard studied). 5 collectors were connected with a rope through a wheel fixed on a steel pillar erected at the plot site for easy collection of the slides. Slide glasses were collected at $6,8,10,12,14,16,18,22$ and 2 o'clock on the following day. The collection was repeated 3 to 5 times of day-night for this vertical pollen experiment

Table 1. - The status of mother trees in Changlinggang seed orchard of Larix kaempferi (2004).

\begin{tabular}{|c|c|c|c|c|c|c|c|c|}
\hline \multirow{2}{*}{$\begin{array}{l}\text { Index of } \\
\text { statistics }\end{array}$} & \multirow{2}{*}{$\begin{array}{l}\text { Jeight } \\
\text { (n) }\end{array}$} & \multirow{2}{*}{$\begin{array}{l}\text { D.B.H. } \\
(\mathrm{cm})\end{array}$} & \multirow{2}{*}{$\begin{array}{l}\text { Crown } \\
(\mathrm{m})\end{array}$} & \multirow{2}{*}{$\begin{array}{l}\text { Number of the } \\
\text { first grade } \\
\text { branch on trunk }\end{array}$} & \multicolumn{4}{|c|}{$\begin{array}{l}\text { Male cone number growing on a branch belonging to the } \\
\text { first grade branches }\end{array}$} \\
\hline & & & & & Last & West & South & North \\
\hline $\begin{array}{l}\text { Numbet of } \\
\text { samples }\end{array}$ & 100 & 100 & 100 & 100 & 300 & 300 & 300 & 300 \\
\hline Mean & 10.51 & 15.57 & 7.29 & 23.33 & 61.07 & 85.13 & 54.00 & 42.10 \\
\hline SD & 9.74 & 17.23 & 8.45 & 4.26 & 12891 & 146.10 & 90.25 & 73.47 \\
\hline$C V \%$ & 92.67 & 110.66 & $115.9 \mathrm{I}$ & 18.26 & 211.09 & 171.62 & 167.13 & 174.51 \\
\hline
\end{tabular}


during the dispersal season in the seed orchard. Apart from all collectors and plot sites in the seed orchard in 2004, 5 pollen collectors were set up at centre, mid and outside places of mother tree crown in 2005.

The average pollen density $(\mathrm{x})$ and its standard deviation ( $\mathrm{s}$ ) can be calculated from the pollen counts on the slide glasses. Using the distribution index $I=s / x$, the pollen distribution type in the seed orchard was evaluated.

The suitable number of accumulating pollen during pollination per area and the suitable number of maximum accumulation pollen per day and per area can be decided by means of the area of the protein liquid ball at the ovule aperture of Cunninghamia lenceolata (ZHANG ZHUOWEN, 2004). From this data the accumulation pollen indices ( $\mathrm{Rm}$ and $\mathrm{Ra}$ ) can be calculated. With $\mathrm{Ra}$ and $\mathrm{Rm}$ the pollination level in a seed orchard can be estimated. Ra here is the ratio of the actually accumulating pollen to the suitable number of accumulating pollen per area during the whole dispersal season in the seed orchard. Rm here is the ratio of the real maximum number of accumulating pollen to the suitable number of maximum accumulating pollen at pollination peak per day and per area in the seed orchard.

\section{Result and discussion}

\subsection{The pollen dispersal rhythm of Larix kaempferi in the seed orchard}

\subsubsection{The pollen dispersal date rhythm}

Male cones of Larix kaempferi disperse pollens from March to April every year, with the dispersal period lasting for about 15 days. The starting date, duration and the end date was determined by the climatic conditions in the seed orchard. Trees began to disperse pollens from March $21^{\text {th }}$ to April $7^{\text {th }}$ in 2004; the average pollen density was 18.036 grains $\cdot \mathrm{cm}^{-2} \cdot$ day $^{-1}$ in the air; 59.666 grains $\cdot \mathrm{cm}^{-2} \cdot$ day $^{-1}$ at the peak-date March $27^{\text {th }}$ to 29th; and the maximum pollen density was 91.060 grains $\cdot \mathrm{cm}^{-2} \cdot$ day $^{-1}$ on March $27^{\text {th }}$. After this the pollen density substantially decreased, because of a small rain event. Another pollen density peak appeared on April $1^{\text {st }}$ on a sunny day, and after the second peak the pollen density gradually decreased until zero. As for the effect of climatic factors on pollen dispersal, Larix kaempferi dispersed pollens 14 days later in 2005 than in 2004, and the season lasted for 11 days from April $4^{\text {th }}$ to $14^{\text {th }}$. The average pollen density was 21.729 grains $\cdot \mathrm{cm}^{-2} \cdot$ day $^{-1}$ in the air; the pollen density peak appeared on April $7^{\text {th }}$ to $8^{\text {th }}$ with a pollen density of 98.918 grains $\cdot \mathrm{cm}^{-2} \cdot$ day $^{-1}$; and the maximum pollen density was on April $7^{\text {th }}$ with 171.278 grains $\cdot \mathrm{cm}^{-2} \cdot$ day $^{-1}$.

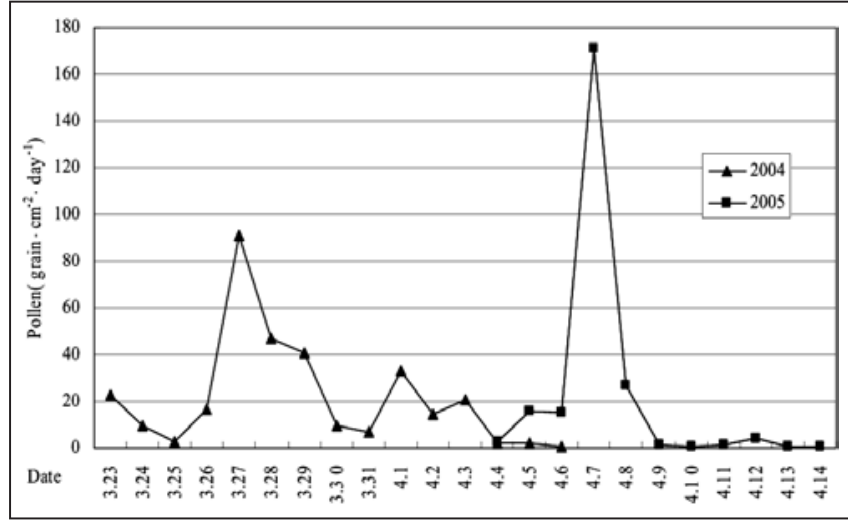

Figure 2. - Pollen dispersal date rhythm during pollen dispersal in the seed orchard of Larix kaempferi.

Because of a heavy rain on April $8^{\text {th }}$, the pollen density was very low. Another pollen density peak appeared on April $12^{\text {th }}$, but pollen dispersal was finished two days later (Fig. 2).

Weather conditions had an effect on the pollen dispersal date rhythm (ZHANG ZHUOWEN et al., 2002a, 2002b, 2004), such as on the starting date of dispersal, peak time and duration, the pollen density in the air etc. Pollens were able to disperse from sacs after maturation on sunny, gently windy days with low relative humidity, but were not able to disperse on cloudy or rainy days. With pollen density information and data on temperature, relative humidity, wind speed and atmospheric pressure in 2005, a regression can be obtained by means of the stepwise regression method. Getting rid of temperature, relative humidity, and atmospheric pressure, the pollen density is related to the wind speed:

\section{$\mathrm{N}=8.6145+11.4238 \mathrm{~V}$}

$\mathrm{N}$ here is the pollen density in the air (grains $\cdot \mathrm{cm}^{-2}$. $\mathrm{day}^{-1}$ ), and $\mathrm{V}$ here is the wind speed $\mathrm{m} \cdot \mathrm{s}^{-1}$ ).

Pollination finished very quickly after the pollen dispersal peaks (Fig. 1). The rhythm of pollen density in the air is low-high-low. In order to test pollen density differences among different dates, analyses of variance (ANOVA) were carried out for the data of two years. As a result, pollen density differences among different dates were highly significant. Because data of both 2004 and 2005 had the same pattern, only the results of the year 2005 are presented in Table 2.

\subsubsection{The pollen dispersal time rhythm}

The pollen dispersal varies because of the changes in temperature, relative humidity, atmospheric pressure and wind speed. Chinese fir pollen dispersal experi-

Table 2. - Analysis of variance for pollen density among dates during pollen dispersal in the seed orchard of Larix kaempferi.

\begin{tabular}{cccccc}
\hline Variance Origin & Sum of Squares of Deviations & Degrec of Frcedom & Mcan Square & F & Fon crit \\
\hline Dates & 1141209.00 & 10 & 114120.91 & $246.35^{* * *}$ & 2.36 \\
Error & 224208.90 & 484 & 463.24 & & \\
Total & 1365418.00 & 494 & & & \\
\hline
\end{tabular}




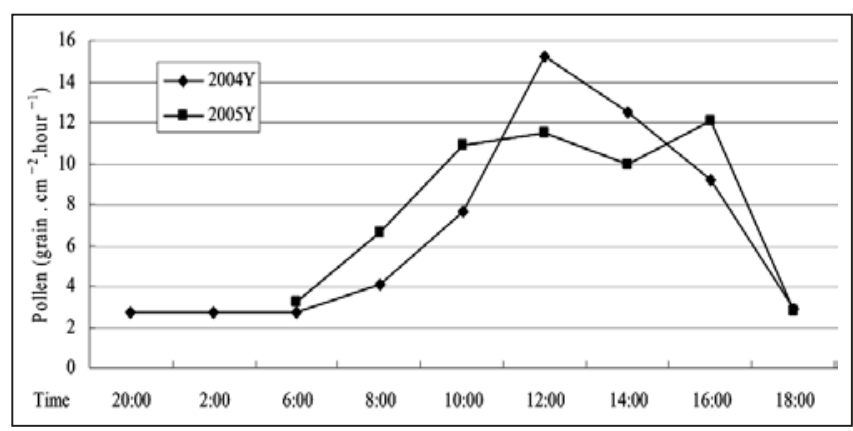

Figure 3. - Pollen dispersal time rhythm during the pollen dispersal peak in the seed orchard of Larix kaempferi.

ments showed a minimum pollen density from 22 to 2 o'clock, and a maximum density from 10 to 12 o'clock, with a second peak at 14 to 18 o'clock, describing a rhythm of low-high-low (ZHANG ZHUOWEN, 2002a). Larix kaempferi pollen dispersal had the same time rhythm as Chinese fir, and the minimum pollen density was at 22 to 2 o'clock, the maximum was at 10 to 16 o'clock, and the peak time was at 10 to 12 o'clock with 15.209 grains $\cdot \mathrm{cm}^{-2} \cdot$ hour $^{-1}$ in 2004 ; and the minimum pollen density was at 0 to 2 o'clock, the maximum at 14 to 16 o'clock, and the peak time was at 10 to 12 o'clock with 12.050 grains $\cdot \mathrm{cm}^{-2} \cdot$ hour $^{-1}$ in 2005 (Fig. 3). An analysis of variance of pollen density showed that there was a highly significant difference among day times. Because the data of both 2004 and 2005 had the same pattern, only the results of year 2005 are presented in Table 3.

\subsection{Spatial distribution of Larix kaempferi pollen during dispersal in the seed orchard}

\subsubsection{Horizontal pollen distribution}

\subsubsection{Pollen density in different directions}

The maximum pollen density was observed in the southwest direction sector with 19.596 grains $\cdot \mathrm{cm}^{-2} \cdot$ day $^{-1}$, and the minimum one in the east direction sector with 16.672 grains $\cdot \mathrm{cm}^{-2} \cdot$ day $^{-1}$ and an average for all eight directions of 18.036 grain $\cdot \mathrm{cm}^{-2} \cdot$ day $^{-1}$ in this seed orchard in 2004 . The maximum pollen density was found in the northwest direction sector with 21.729 grains $\cdot \mathrm{cm}^{-2}$. day ${ }^{-1}$, and the minimum one in the east direction sector with 17.768 grains $\cdot \mathrm{cm}^{-2} \cdot$ day $^{-1}$ and an average for all eight directions of 20.102 grains $\cdot \mathrm{cm}^{-2}$. day ${ }^{-1}$ in 2005 (Fig. 4).

The distribution index suggested an even pollen distribution across directions. The results of an analysis of variance for both 2004 and 2005 showed that the differences in pollen density among the eight directions were not significant. Although some research showed that

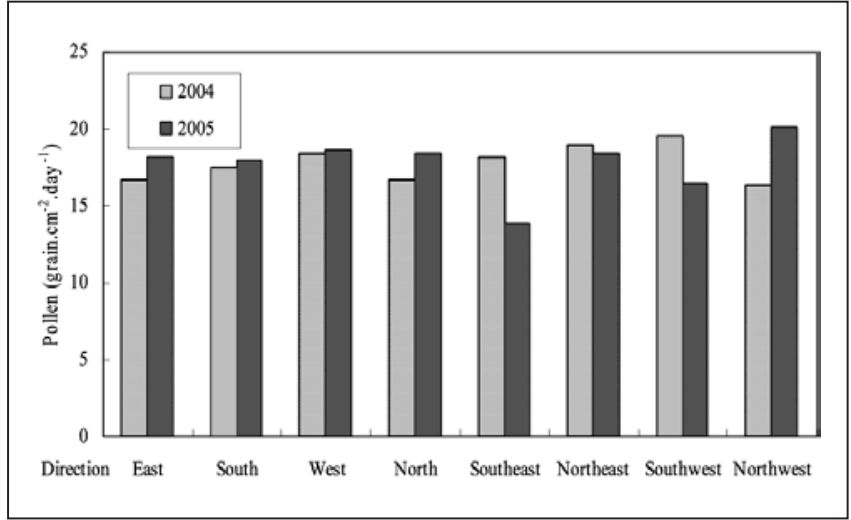

Figure 4. - Pollen densities for different directional sectors in the seed orchard of Larix kaempferi.

there were some differences for pollen numbers among different mountain topography conditions, these differences were not significant in statistics, so the condition of mountain topography did not play a very important roles in the pollen distribution (ZHANG ZHUOWEN et al., 1990; Chen Xiaoyang et al., 1996), and they did not either in this seed orchard.

\subsubsection{Pollen density in different places of the mother tree crown}

The pollen density inside the crown was less than that at the outside of the crown. The pollen density outside the crown was 27.999 grains $\cdot \mathrm{cm}^{-2} \cdot$ day $^{-1}$, which was 1.068 times of that inside the crown (Fig. 5). Though there were some differences in pollen density among different places in the tree crowns, these differences were not significant.

\subsubsection{Pollen density in different districts of the seed} orchard

There were some differences in pollen density among districts in this seed orchard. The pollen densities in

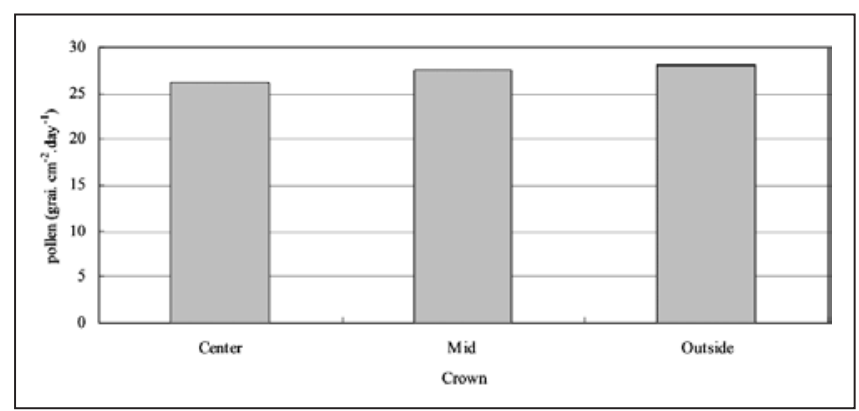

Figure 5. - Pollen distribution in different positions of tree's crown in the seed orchard of Larix kaempferi.

Table 3. - Analysis of variance for pollen density among day times during the pollen dispersal peak in the seed orchard of Larix kaempferi.

\begin{tabular}{cccccc}
\hline Variance Origin & Sum of Squares of Deviations & Degree of Freedom & Mean Square & $F$ & $F_{0,0 y}$ crit \\
\hline Time & 53038.42 & 6 & 8839.74 & $109.48^{* *}$ & 2.86 \\
Frror & 24868.84 & 308 & 80.74 & & \\
Total & 77907.26 & 314 & & & \\
\hline
\end{tabular}


district A, B and C were 22.521 grains $\cdot \mathrm{cm}^{-2} \cdot$ day $^{-1}$, 17.666 grains $\cdot \mathrm{cm}^{-2} \cdot$ day $^{-1}$ and 15.627 grains $\cdot \mathrm{cm}^{-2} \cdot$ day $^{-1}$, respectively in 2004 . The maximum pollen density was observed on a glass slide in district B with 22.927 grains $\cdot \mathrm{cm}^{-2} \cdot \mathrm{day}^{-1}$ and the minimum on a glass slide in district A with 15.016 grains $\cdot \mathrm{cm}^{-2} \cdot$ day $^{-1}$ in 2005 , please see Fig. 6.

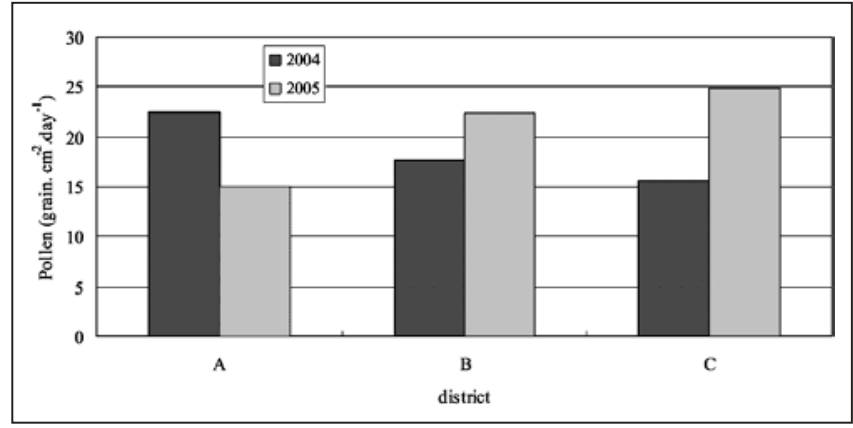

Figure 6. - Pollen distribution in different districts in the seed orchard of Larix kaempferi.

The results of an analysis of variance for both 2004 and 2005 showed that the pollen density differences among districts in the seed orchard were not significant.

The pollen distribution indices I for years 2004 and 2005 were 0.1810 and 0.3520 , respectively, and because of $\mathrm{I}<1$ they belonged to evenly distribution types. These results were possibly due to wind, because both gentle breeze and strong wind could make the pollen distribution evenly.

\subsubsection{Vertical pollen distribution}

Vertical pollen distribution during dispersal in the Larix kaempferi seed orchard for both 2004 and 2005 were the same (Fig. 7). For example, the maximum pollen density on a glass slide was at crown bottom with 70.196 grains $\cdot \mathrm{cm}^{-2} \cdot \mathrm{day}^{-1}$; the minimum at tree tops with 33.928 grains $\cdot \mathrm{cm}^{-2}$. day ${ }^{-1}$ in 2004 . In order to test pollen density differences among different heights, an analysis of variance (ANOVA) was carried out. As a result, pollen density differences among the different heights were found to be highly significant, and because the data of both 2004 and 2005 had the same pattern, only the results of year 2005 were presented in Table 4. Due to the index of distribution $\mathrm{I}>1$, this was a cluster distribution type.

\subsection{Pollination level in the seed orchard during dispersal}

The pollination level of Larix kaempferi was determined not only by pollination characteristics, tree num-

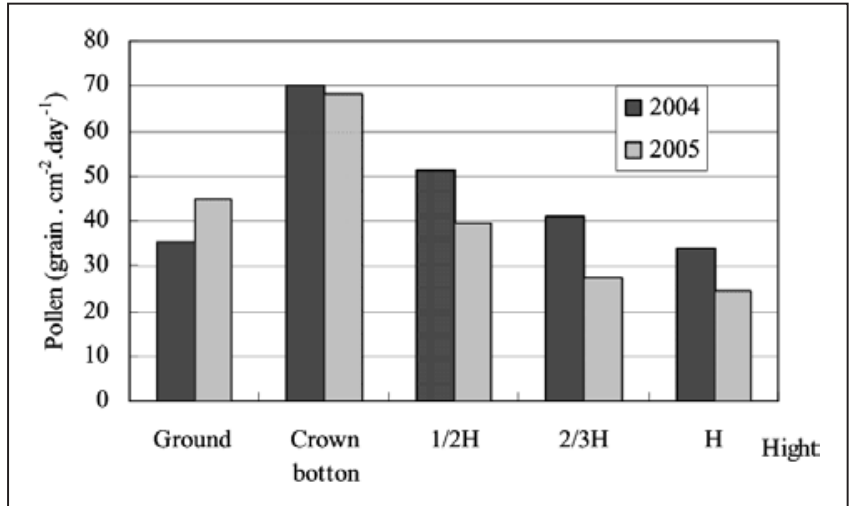

Figure 7. - Pollen distribution in different vertical heights in the seed orchard of Larix kaempferi.

ber, tree age, density, etc., but also by wind velocity. The indices of $\mathrm{Rm}$ and $\mathrm{Ra}$ had been used to estimate the pollination level in a Chinese fir seed orchard before (ZHANG ZHUOWEN, 2004). It was observed that the area of protein liquid ball at the ovule aperture of Larix kaempferi was about 0.6 to $1.0 \mathrm{~mm}^{2}$. If there are 3 to 5 pollen grains at the ovule aperture, this is enough for fertilization. So the suitable number of accumulating pollen during the whole pollen dispersal season should be 4 pollen grains $\cdot \mathrm{mm}^{-2}$, and the suitable maximum number of accumulating pollen at pollination peak 3 pollen grains $\cdot \mathrm{mm}^{-2} \cdot \mathrm{day}^{-1}$. Accordingly, the pollination level of a Larix kaempferi seed orchard could be estimated using the two indices.

The maximum accumulation pollen density for one glass slide was 442.2336 grains $\cdot \mathrm{cm}^{-2}$, the minimum 215.8521 grains $\cdot \mathrm{cm}^{-2}$, the average $324.6556 \mathrm{grains} \cdot \mathrm{cm}^{-2}$ during pollination, and the pollen density peak was March $27^{\text {th }}-29^{\text {th }}$ with 59.6664 grains $\cdot \mathrm{cm}^{-2}$. day $^{-1}$ in 2004. By contrast the maximum accumulating pollen density for one glass slide was $412.2636 \mathrm{grains} \cdot \mathrm{cm}^{-2}$, the minimum 89.49965 grains $\cdot \mathrm{cm}^{-2}$, the average 239.0167 grains $\cdot \mathrm{cm}^{-2}$ during the pollen dispersal season, and the pollen density peak in the air was April $5^{\text {th }}-8^{\text {th }}$ with 57.2681 grains $\cdot \mathrm{cm}^{-2} \cdot$ day $^{-1}$ in 2005 (Table 5).

Because both $\mathrm{Rm}$ and $\mathrm{Ra}$ were $<1$, the pollination level of the seed orchard was too low. This maybe the key factor that affects seed yield. The seed orchard needs a supplement mass pollination (SMP) in order to produce more seeds.

\subsection{Supplement mass pollination}

For a supplement mass pollination, the following steps need to be performed:

Table 4. - Analysis of variance for pollen density at different vertical heights during pollen dispersal peak dates in the seed orchard of Larix kaempferi.

\begin{tabular}{cccccc}
\hline Variance Origin & Sum of Squares of Deviations & Degrce of Frecdom & Mcan Square & $F$ & Fo.ul crit \\
\hline I leight & 2715.03 & 4 & 678.76 & $11.85^{* *}$ & 5.99 \\
Error & 572.82 & 10 & 57.28 & & \\
Totat & 3287.84 & 14 & & & \\
\hline
\end{tabular}


Table 5. - Accumulation pollen number during pollination.

\begin{tabular}{cccccc}
\hline \multirow{2}{*}{ Year } & \multicolumn{3}{c}{ Pollen densily (grain. $\mathrm{mm}^{-2}$ ) } & \multicolumn{2}{c}{$\mathrm{R}$} \\
\cline { 2 - 6 } & $\begin{array}{c}\text { Pollen accumulation } \\
\text { during pollination }\end{array}$ & I'er day & $\begin{array}{c}\text { Max per day } \\
\text { (during peak pollination) }\end{array}$ & $\begin{array}{c}\mathrm{Ra} \\
\left(\text { grains } \cdot \mathrm{mm}^{-2} \text { ) }\right.\end{array}$ & $\begin{array}{c}\mathrm{Rm} \\
\text { (grains-mm }^{-2} \cdot \text { day }^{-1} \text { ) }\end{array}$ \\
\hline 2004 & 3.23 & 0.18 & 0.60 & 0.81 & 0.20 \\
\hline 2005 & 2.39 & 0.22 & 0.57 & 0.52 & 0.19 \\
\hline
\end{tabular}

(1). Pollen collection: At 10 to 15 o'clock on a fine day, pollens should be collected using the following procedures:

a. Just before the male cones disperse pollens, cover the cones with a paper bag and shake the twig.

b. Cut twigs before pollen dispersal and place them in a container with water in a closed room, then put the container with the twigs on a piece of paper. When the sacs open, pollens fall onto this paper.

(2). Pollen drying: Transfer the collected pollens into a $500 \mathrm{ml}$ clean bottle, fill only half of the bottle. Put the bottle with pollens into a desiccator during drying. The experiment shows that pollen moisture content is the most important factor to maintain pollen viability. The pollen moisture content should be less than $10 \%$.

(3). Pollen storage: Put sealed bottles with pollens into a refrigerator. The temperature should be 0 to $5{ }^{\circ} \mathrm{C}$, or -5 to $0{ }^{\circ} \mathrm{C}$ to keep pollens alive longer.

(4). Supplement mass pollination: When female cones open in the seed orchard pollens can be sprayed with a sprayer at 10 to 16 o'clock on a fine day. Attention should be paid to the topography and the direction of wind when spraying pollens. If the quantity of pollens is limited pollens can be mixed with talcum powder before spraying. Never spray with water.

\section{Conclusions}

Larix kaempferi pollen dispersal has its own characteristics for time rhythm, date rhythm and spatial distribution, and the pollen dispersal is affected by weather conditions and topography in the seed orchard.

The pollination level in a seed orchard can be estimated by means of $\mathrm{Ra}$ and $\mathrm{Rm}$. The pollination in Changlinggang Larix kaempferi seed orchard is very low and it needs a supplement mass pollination.

\section{Acknowledgements}

The authors are truly indebted to ULRICH APEL for revising the manuscript. Furthermore, we are grateful to the contributions of the seed orchard staff, Li SHIYUAN, Hou YIMEI and others, who assisted in carrying out the research.

\section{References}

Wu Dejun, Cao Hanyu and Wang Guicune et al. (1997): Pollen dispersal and supplement mass pollination in seed orchard of Larix kaempferi. Journal of Shandong Forestry Science and Technology (2): 1-3.

Wu YiqIANG, FAng WenBin and Shi Jiamin et al. (2000): Comparative Study of the Wood Properties between Preponderant Tree and Average Tree of Larix kaempferi (Lamb.) Carr. (Japanese larch). Journal of CentralSouth Forestry University 20(2): 15-21.

Ding Zhenfang, WANG JingZhang and FAng Haifeng et al. (2000): The Growth of Half Sib Progeny in Larix kaempferi Primary Seed Orchard. Journal of Northeast Forestry University 30(2): 9-12.

ZHANG ZHUOwen and Li PING (1990): Study on Ecological Character of Pollen in chinese fir. Scientia Silvae Sinicae 26(5): 410-417.

Zhang ZHUOWen (2002): Pollen dispersal and its spatial distribution in seed orchards of Cunninghamia lanceolata (Lamb.) Hook. Silvae Genetica 51(6): 237-241.

ZHANG ZHUOWEN (2002): Differences in Flowering Characteristic among Clones of Cunninghamia lanceolata (Lamb.) Hook. Silvae Genetica 51(6): 206-209.

ZHANG ZHUOWEN (2004): Studies on the pollination characteristics and pollination level of Cunninghamia lanceolata (Lamb.) Hook. Silvae Genetica 53(1): 7-11.

Wang Youcai, Dong Xiaoguang, Wang Xiaoshan and MA HAO (2000): Study on seed production and fruiting law of seed orchard in Larix kaempferi. Scientia Silvae Sinicae 6(2): 53-59.

Chen Boru, Ma Dingmei and Li ShiYuan (1997): The useful techniques to produce seeds for Larix kaempferi. Forest Science and Technology (8): 15-17. 